University of Louisville

ThinkIR: The University of Louisville's Institutional Repository

Electronic Theses and Dissertations

$12-2006$

\title{
Variation within shape determining processes.
}

Abigail Lindsay Oesterritter

University of Louisville

Follow this and additional works at: https://ir.library.louisville.edu/etd

\section{Recommended Citation}

Oesterritter, Abigail Lindsay, "Variation within shape determining processes." (2006). Electronic Theses and Dissertations. Paper 1079.

https://doi.org/10.18297/etd/1079

This Master's Thesis is brought to you for free and open access by ThinkIR: The University of Louisville's Institutional Repository. It has been accepted for inclusion in Electronic Theses and Dissertations by an authorized administrator of ThinkIR: The University of Louisville's Institutional Repository. This title appears here courtesy of the author, who has retained all other copyrights. For more information, please contact thinkir@louisville.edu. 


\author{
By \\ Abigail Lindsay Oesterritter \\ B.A., Transylvania University, 2000

\begin{abstract}
A Thesis
Submitted to the Faculty of the

Graduate School of the University of Louisville

In Partial Fulfillment of the Requirements

For the Degree of
\end{abstract}

Master of Arts

Department of Fine Art

University of Louisville

Louisville, Kentucky

December 2006 
VARIATIONS WITHIN SHAPE DETERMINING PROCESSES

By

Abigail Lindsay Oesterritter

B.A., Transylvania University, 2000

A Thesis Approved on

August 23, 2006

By the following Thesis Committee:

Thesis Co-Director, Todd Burns

Thesis Co-Director, John Whitesell

Thesis member, Barry Horowitz 


\section{ABSTRACT \\ VARIATIONS WITHIN DETERMINING PROCESSES}

Abigail Lindsay Oesterritter

August 23, 2006

This thesis briefly describes my current body of work, both formally and conceptually. The section titled Pattern Within Form, describes the concepts behind the use of stamps and molds, and the process of separately throwing segments of a single form and attaching them together. It also discusses the visual influences of industrial materials that I have translated onto the surface of the vessel. Process and Material describes a typical reduction cool firing within a wood kiln. It explains the differences between cottonwood, elm, box elder, and pine, as well as the comparisons between a firing that is shut off at peak temperature, and a firing that is fired through its cooling to $1400^{\circ} \mathrm{F}$. This section also describes my continual research within ceramic materials. Artistic Influences and the Conclusion expound on who and what I look to for references and where I see my work going in the near future. 


\section{TABLE OF CONTENTS}

PAGE

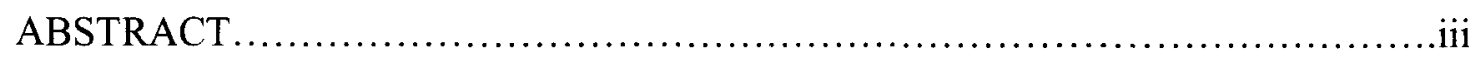

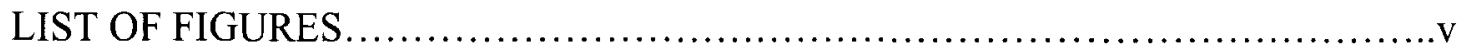

SECTION

I. PATTERN WITHIN FORM.....................................

II. PROCESS AND MATERIAL .....................................

III. ARTISTIC INFLUENCES.........................................11

IV. CONCLUSION ..................................................

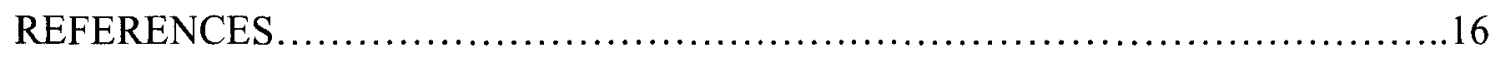

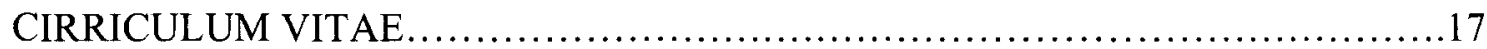




\section{LIST OF FIGURES}

FIGURE

PAGE

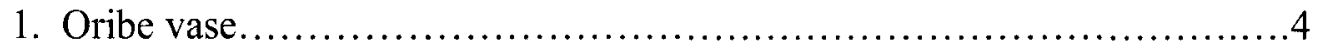

2. Oribe platters........................................................

3. Lindsay Oesterritter bowl............................................ 6

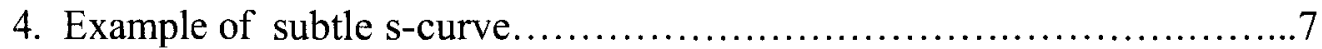

5. Example of a vessel thrown in separate parts............................. 8

6. Mokubei bowl......................................................... 13

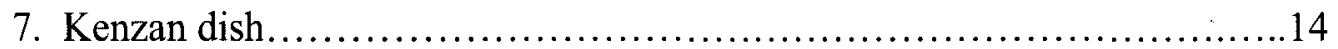

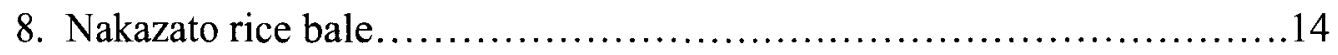




\section{PATTERN WITHIN FORM}

When I started working with the idea of decorating the surface of my pots with patterns, the patterns and forms directly related to my daily four-mile run in historic downtown Louisville. I was drawn to the characteristics of worn industrial equipment, including sewer and drain covers, old automobiles and fire hydrants. My interest was not in the objects themselves as much as it was in the mechanical patterning on them with the additional wearing through natural circumstance. It is the idea of planned and unplanned or organic and inorganic reacting to one another that intrigued me.

Parallel, to this idea, I was also actively researching historic pots. I was looking to ceramic history to get formal ideas and to be able to understand better the sources of traditional forms that are present in modern day ceramics. Oribe pots from the Monoyama period (1573-1615) in Japan instantly intrigued me. Oribe characteristics include intense, rough, magnanimous free forms that distinguished it from other tea ceremony wares of that time. ${ }^{1}$ What specifically captured my attention with these wares was the non-affectatious interplay between the brushed designs and glaze application. A characteristic Oribe ware generally included a painted grid based on something within the natural environment or a fabric pattern, next to a glossy drippy green glaze. The forms I was attracted to were very simple, often geometric shapes (Figure 1 and 2). I was drawn

\footnotetext{
${ }^{1}$ Kuroda, Ryoji and Murayama, Takeshi, (2002).Classic Stoneware of Japan, Shino and Oribe, Kodansha International New York, p 37
} 
to this combination of varied surface treatments and it related similarly to concepts I was beginning to explore in my own work.

Using Oribe as inspiration for surface decoration, I started combining abstract representations of seeds and pods with loosely executed linear grids (Figure 3). However, while I was working in this fashion I became less interested in painting on the surface of the pot, and more interested in carving or impressing the clay, affecting the texture and form. The transition from brushwork to impressing and carving clay was a natural progression. I was firing a salt kiln at the time, and a pot with a textured surface better suited that type of firing than brushwork alone.

It was not until I moved to Utah that I really began to explore impressing clay in a way that not only created patterns as a texture but also altered the form itself. I discovered that if I pressed hard enough into soft enough clay, the patterns would appear inversely on the interior of the vessel, also accentuating the form. After noticing how much a stamp or impression could alter the form, I started throwing simpler forms, for example, a cylinder with a subtle s-curve, or a bowl with a wide rim at the top. The forms were directly influenced by how the stamps would affect them, essentially becoming a general shape that the stamp would then define (Figure 4).

The stamps and molds I use are both found and created. The stamps are made from wood, plaster, metal, or bisqued clay. The patterns or shapes themselves are based greatly on designs I have found within industrial materials, such as manhole covers, drains, and vent screens. It is through this variety of material and simple geometric shapes that I explore the variations that happen when an exacting stamp is impressed into soft clay. 
A secondary more process oriented pattern that has developed, is the way the pots are put together. As I have just mentioned, the use of stamps directly influenced the progression of the forms. After simplifying the form on the wheel, I began separating the form itself into units or segments. This is something I had worked on prior to Utah, however, it was not until I watched Takashi Nakazato putting together a traditional rice bale, in a similar fashion, that I was inspired to revisit this process. Outside of the tumblers and bowls, all the forms are thrown in separate pieces, or units as I have begun to call them, and then attached together after they are trimmed and stamped. While I do not fully understand why I work this way, I am continually motivated to create new ways to further separate the parts of a single vessel, enjoying the potential within the possibilities of the finished form. Within this additional process there are seams or juncture points that I leave visible. This allows the viewer access to part of the process of how the pot was made (Figure 5). Similarly, with my platters made from a press mold, I will leave the seams from the sections of clay I press into the mold visible. This again, exposes the process I am using, but also creates subtle variations within the form.

It is the process of throwing separate units and then attaching them along with the use of molds and stamps as a determining process that has become the basis for all of my forms. This way of working allows me to discover new and exciting relationships between proportion and form, as well as letting the clay remain expressive within the variations of surface and juncture points. 


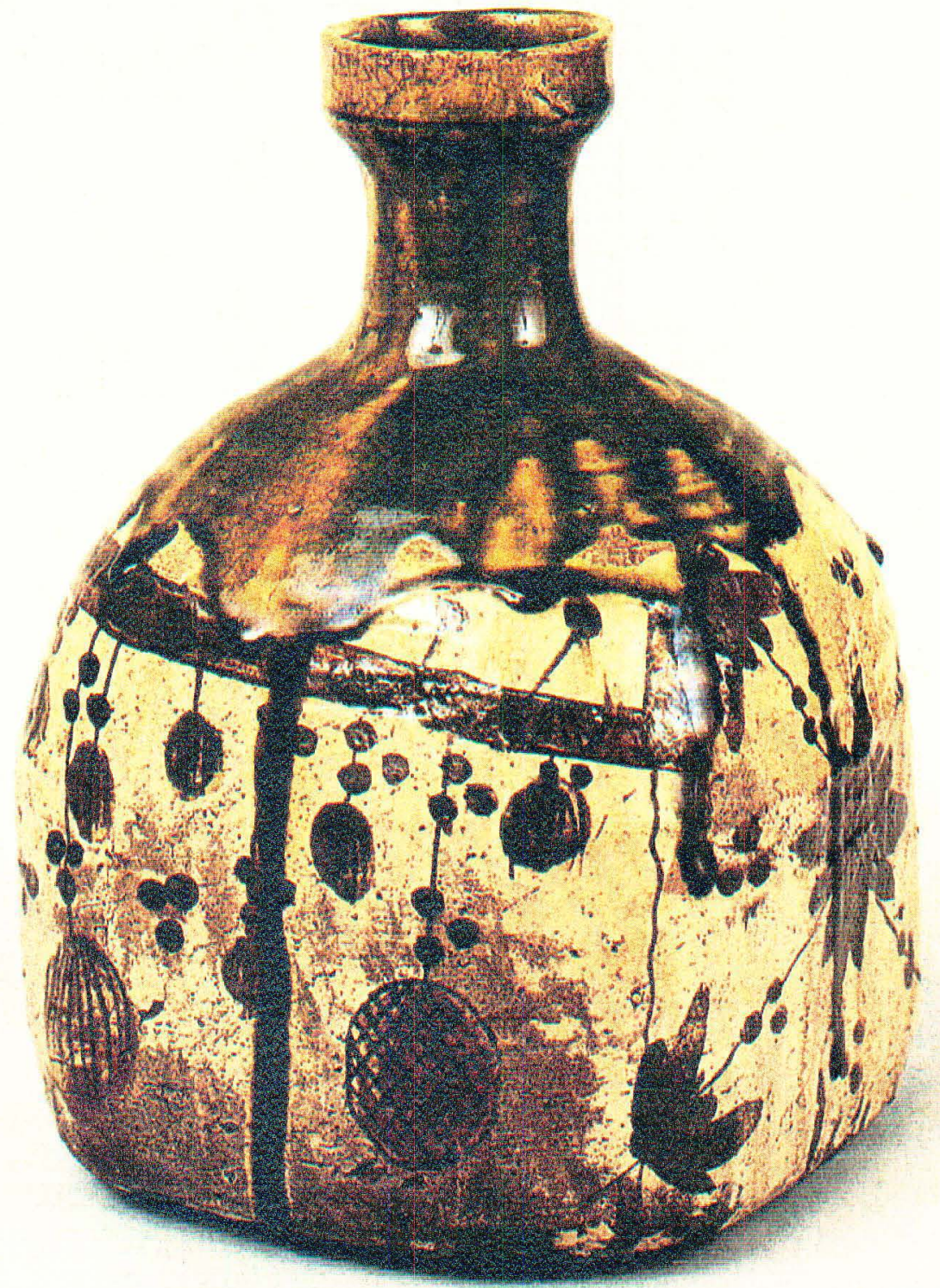

Figure 1- Oribe vase

(original context, Kuroda, R. \& Murayama, T, p86) 

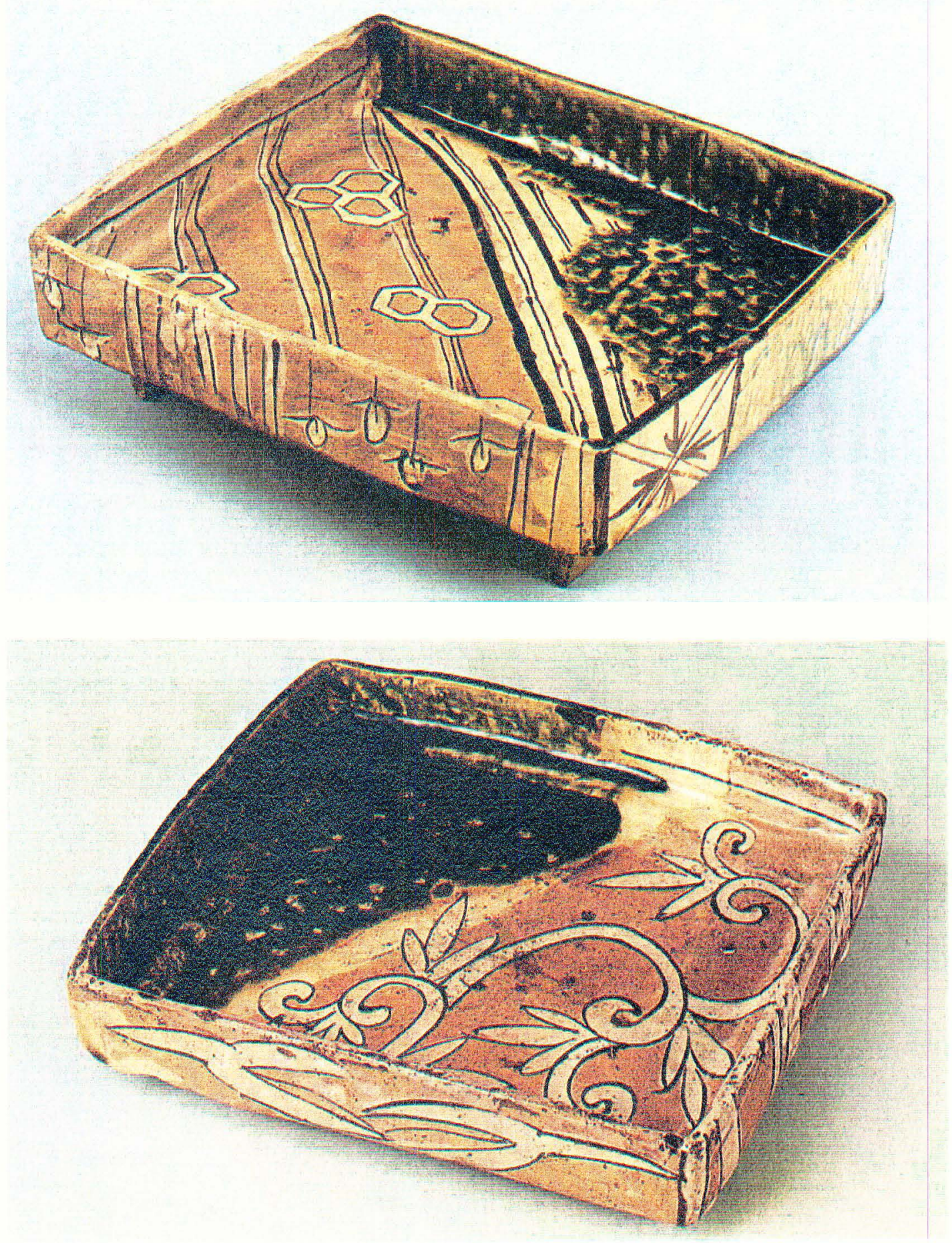

Figure 2- Oribe platter

(original context, Kuroda, R. \& Murayama ,T., p78) 


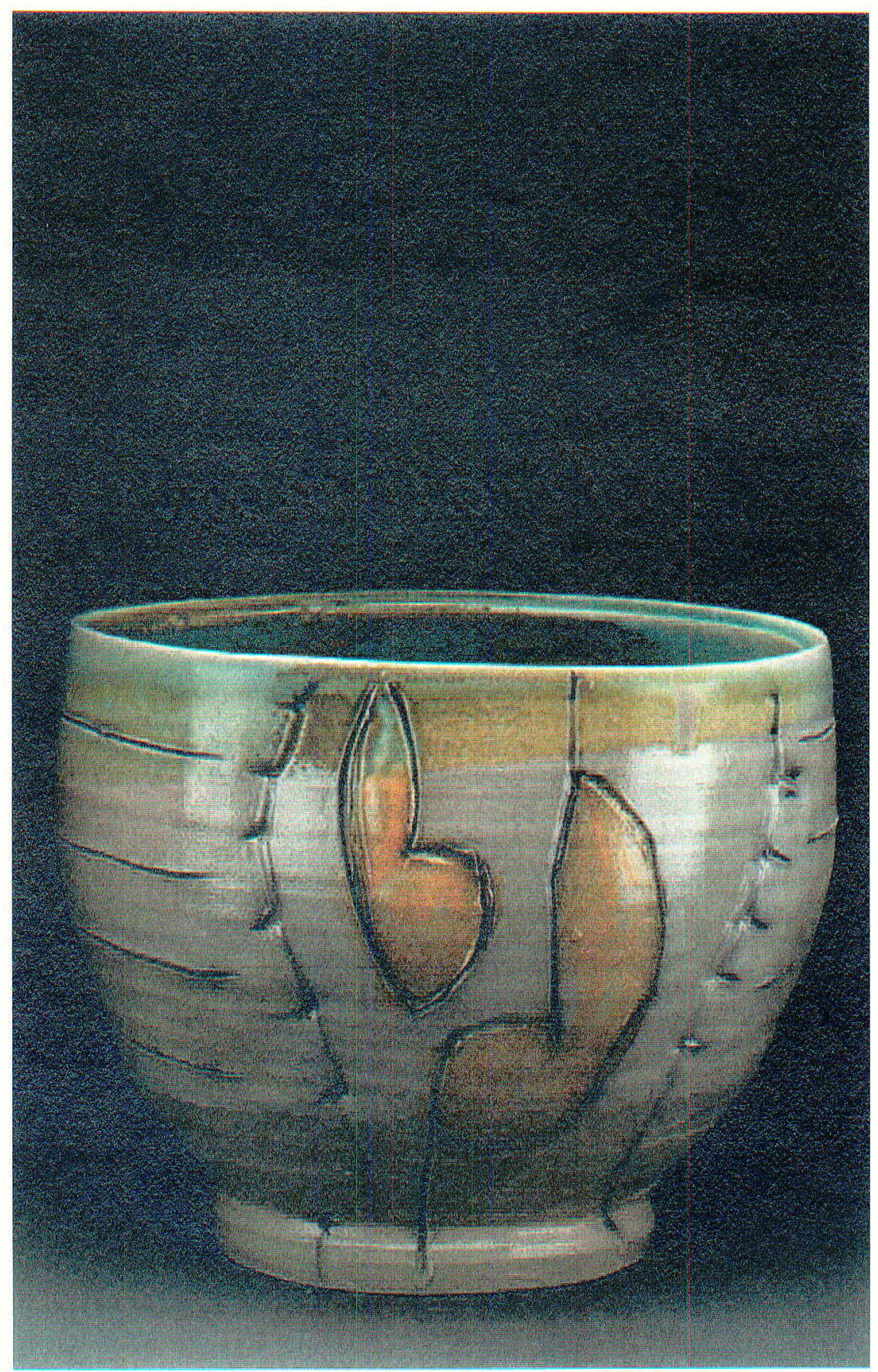

Figure 3- Lindsay Oesterritter bowl (Photograph taken by Lindsay Oesterritter) 


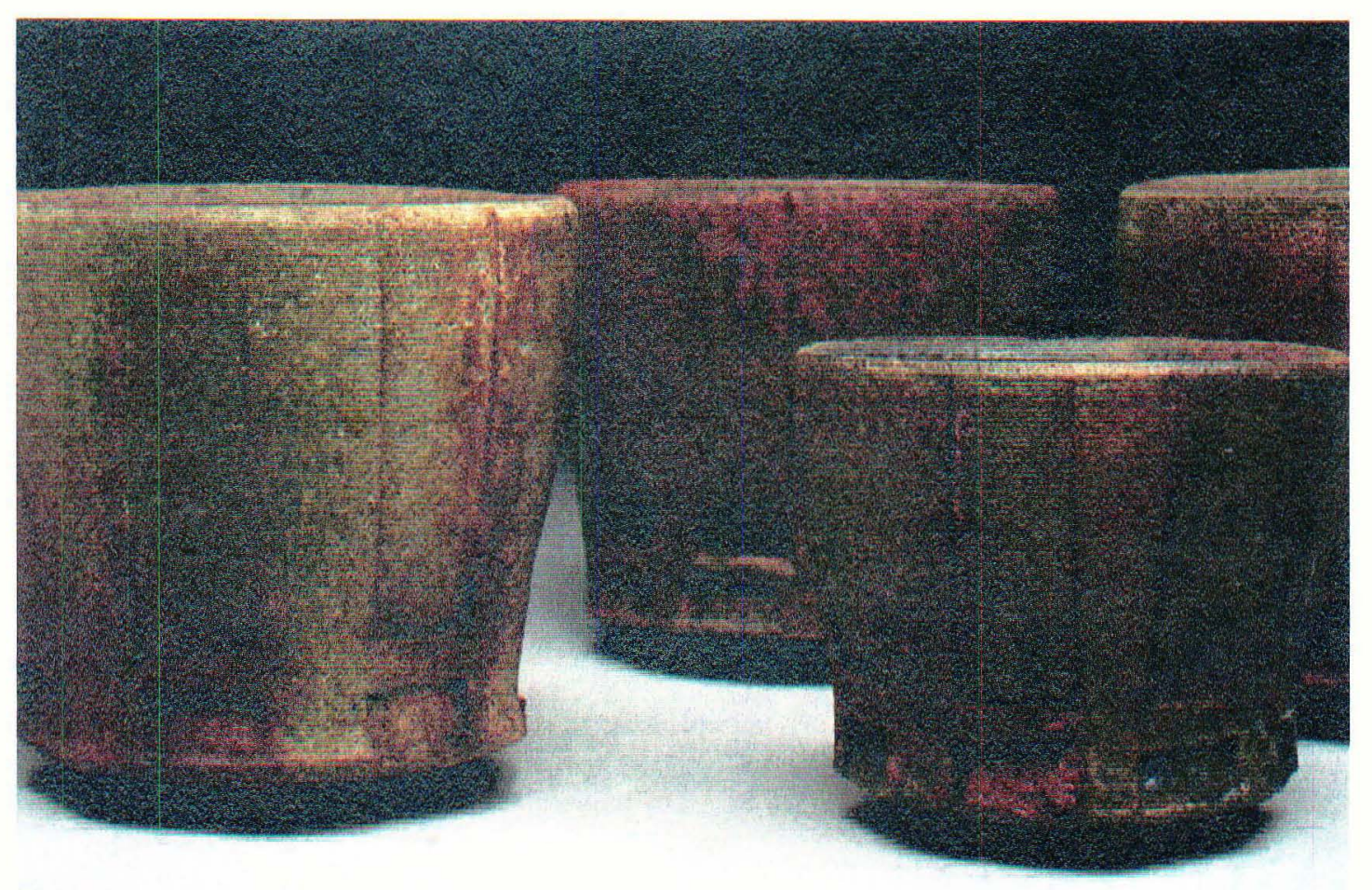

Figure 4- Example of cylinders with a subtle s-curve that have been impressed with a wooden stamp.

(Photograph taken by Lindsay Oesterritter) 


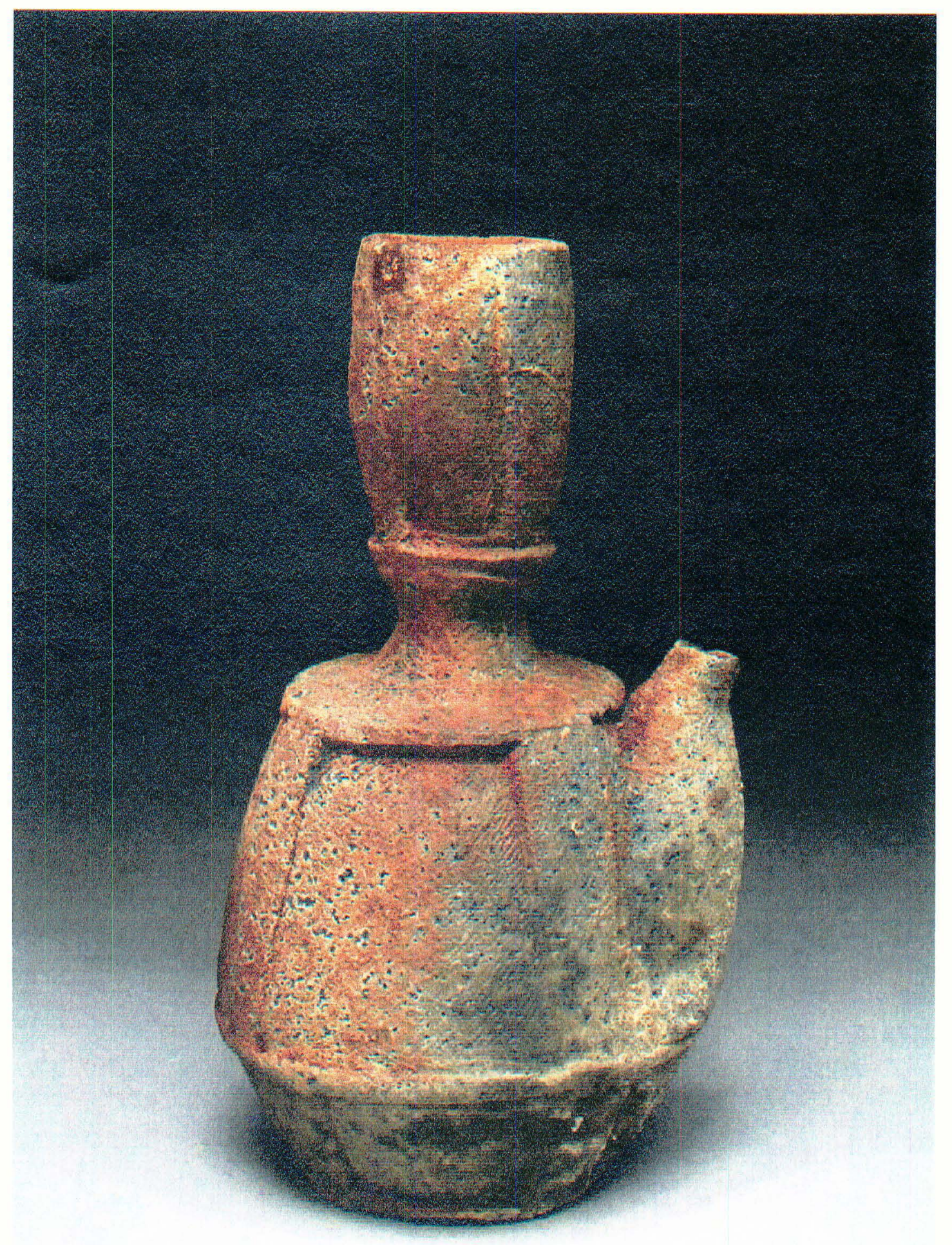

Figure 5-Example of an oil cruet that has been made with five separate segments. (Photograph taken by Lindsay Oesterritter) 


\section{PROCESS AND MATERIAL}

I fire reduction cool in a wood kiln, firing up to cone $9\left(2200^{\circ} \mathrm{F}\right)$, and then back down to $1400^{\circ} \mathrm{F}$. A typical firing lasts approximately forty hours. It is necessary to fire the kiln this length of time to obtain sufficient ash build up on the surface of the pots. After experimenting with different types of wood and the effects they have within the kiln, I have discovered that a combination of cottonwood, elm, box elder and pine, produces the desired effects. Cottonwood, elm and box elder all produce a substantial amount of coal in the kiln without producing as much heat as pine. If there is too much coal build up in the kiln, the coal actually begins to clog or block the airflow through the kiln, making it difficult to keep the temperature steady while continually depositing ash on the surface of the pots. Pine contrastingly, produces a low amount of coal but a long lasting amount of heat.

However, pine's affect on the surface of the pots is not as desirable. Pine tends to look yellow and runny, while the drips of ash from elm or box elder tend to happen less frequently, and can be anything from red to dark yellow, with a more matte finish. Cottonwood yields a very dry surface with subtle flashing ranging from green, gray, orange and more rarely purple or blue. By using a combination of these woods I am able to produce depth within the surface variation of my pots as well as hold the kiln at specific temperatures without developing a profuse amount of coal.

Typically, when a reducing kiln is shut off at peak temperature, lacking the necessary fuel, the kiln becomes oxidized, allowing the pots to reoxidize and produce 
lighter tones within the clay body. A high iron clay body, for example, might appear red or brown. By cooling the kiln to $1400^{\circ} \mathrm{F}$ in a reducing atmosphere I am not allowing black iron to reoxidize to red iron oxide on the surface of the vessel, yielding black with a high iron clay body. The flashing on a pot reduced to $1400^{\circ} \mathrm{F}$ is also darker in tone, and does not follow the flame pattern within the kiln as much as it relates to the pot's placement in the kiln and the way the kiln was stacked. The red on the pots within the exhibition is caused by localized reoxidation around $1400^{\circ} \mathrm{F}$. Generally, this happens in lower regions of the kiln, where the coals are covering the vessels, or where the pots are stacked closely together. While I stop cooling the kiln at $1400^{\circ} \mathrm{F}$, the coals and stacks of pots will hold their heat longer than the rest of the kiln, staying at a temperature (above $1400^{\circ} \mathrm{F}$ ) that is still able to reoxidize.

The varied dry, dark surface from this type of firing directly relates to the surface qualities of the materials I look to for pattern ideas, and connects to my personal sensibility. I enjoy the quiet nature of such a dry surface, creating subtle variations that are not immediately noticed.

Firing reduction cool is the first time I have ever thought about controlling the temperature of the kiln and or the length of the cooling. This type of firing has made me aware that, by controlling the atmosphere within the kiln, and the rate of cooling, I can change the results of the firing. This idea of lengthening the cooling process has also started me on an investigation with the salt gas kiln, specifically with a Wollastonite clay body. Unlike the clays I am currently using in the reduction cool kiln, the Wollastonite body is affected less by the atmosphere being in a state of reduction or oxidation, and more by the length of the cooling. 
Finding a clay body that suits me has been a source of constant exploration and discovery. I have yet to settle on any clay, however, for the purpose of this examination I will mention the most influential within the exhibition. Specifically, I use high iron stoneware bodies, or buff stoneware bodies that I slip with a high iron clay (Red Art or an iron ore, Crocusmartis). I use Lesch-Middleton stoneware for the tumblers and mugs. It is a tight stoneware that yields a smooth, polished surface pleasing to drink from. Extended $50 / 50$ stoneware is more open and coarse. It is good for hand building and also has a gritty texture that works well with stamping and press molds, producing subtle roughness at the edges of the forms. When I work with buff stoneware and then slip it with a high iron clay, it is because of the variations within the flashing, changing from the lighter gray tones of the visible clay, to the dark black, red, green, and sometimes purple and yellow tones of the slip itself. A slip also tends to allow for more variation within texture and color. Being more interested in the surface effects of the clay body in the wood kiln I only use a liner glaze when it adds to the function of the pot.

Wollastonite Body Imco $800 \quad 48$ Tennessee Ball Clay 35 Wollastonite $\quad 17$ Mixed Grog $\quad 50$

\section{$\underline{50 / 50 \text { Extended }}$}

\begin{tabular}{lll}
\hline Holmes & & 37.5 \\
Lizella & & 37.5 \\
Imco 400 & & 22.5 \\
Foundry Hill & & 3 \\
Custer & 5 \\
Sand & & 10
\end{tabular}

Being particularly process oriented, my sketchbook acts as a springboard for general formal and conceptual ideas. From the sketchbook I make three to four initial forms. Reworking or focusing on aspects from those three dimensional sketches, I develop one or more forms into a series. I hand build and throw on a kick wheel. All the 
platters have been made with a press mold. All the other forms were thrown on the wheel in two or more parts and then assembled to complete the form. I use the press mold as the determining process for the shape of the platter. While pressing slabs or coils into the mold I vary the amount of pressure I put onto the clay in the mold, and the routine of how I place the clay into the mold. These variations of pressure and placement aid in the distinctions between the platters produced. Similarly to the molds, I use the stamps as a determined impression, varying the placement and how hard I press them into the form, to produce distinctions within the surface and texture within a vessel. 


\section{ARTISTIC INFLUENCES}

Many people have influenced me throughout my explorations in clay. There is not one person who stands out as an overwhelming influence, as much as I hold many small admirations for a group of passionate and intelligent artists and educators, both historically and in the present.

Influenced early by Oribe ware, I have continued to look to Japan for ideas. Specifically, Mokubei and Kenzan, potters during the Edo period (1616-1868), have influenced me. Mokubei influenced me with his sophisticated use of sprigs and molds (Figure 6). I admire his ability to let the clay move within a mold, being able to keep a freshness with a determined line. Kenzan has inspired me with his repetition between contours of the form and the brushwork. "Kenzan ware managed to be at once poetic and potlike"2 (Figure 7). Takashi Nakazato, a modern day Karatsu potter, has influenced me by his beautiful yet unusual combinations of proportion and form (Figure 8). These wares have broadened my idea of what is beautiful and motivated me to experiment within my own work. But, almost more importantly, Takashi has influenced me with his spirit. He has such an ability to live in the moment, actively learning new things at 72 years old, telling stories of making 700 bowls a day in his youth, sharing with everyone his knowledge, and laughing when someone asks him how much he sells his work for.

Takashi Nakazato, Richard Parker, and Elisa Helen-Hansen are a few of the many

\footnotetext{
${ }^{2}$ Wilson, Richard L. (1991). The Art of Ogata Kenzan Persona and Production in Japanese Ceramics, Weatherhill, New York, p 16
} 
modern day studio potters that have amazed and inspired me by their energy, commitment, and continual research within their field. I aspire to contribute to this community. 


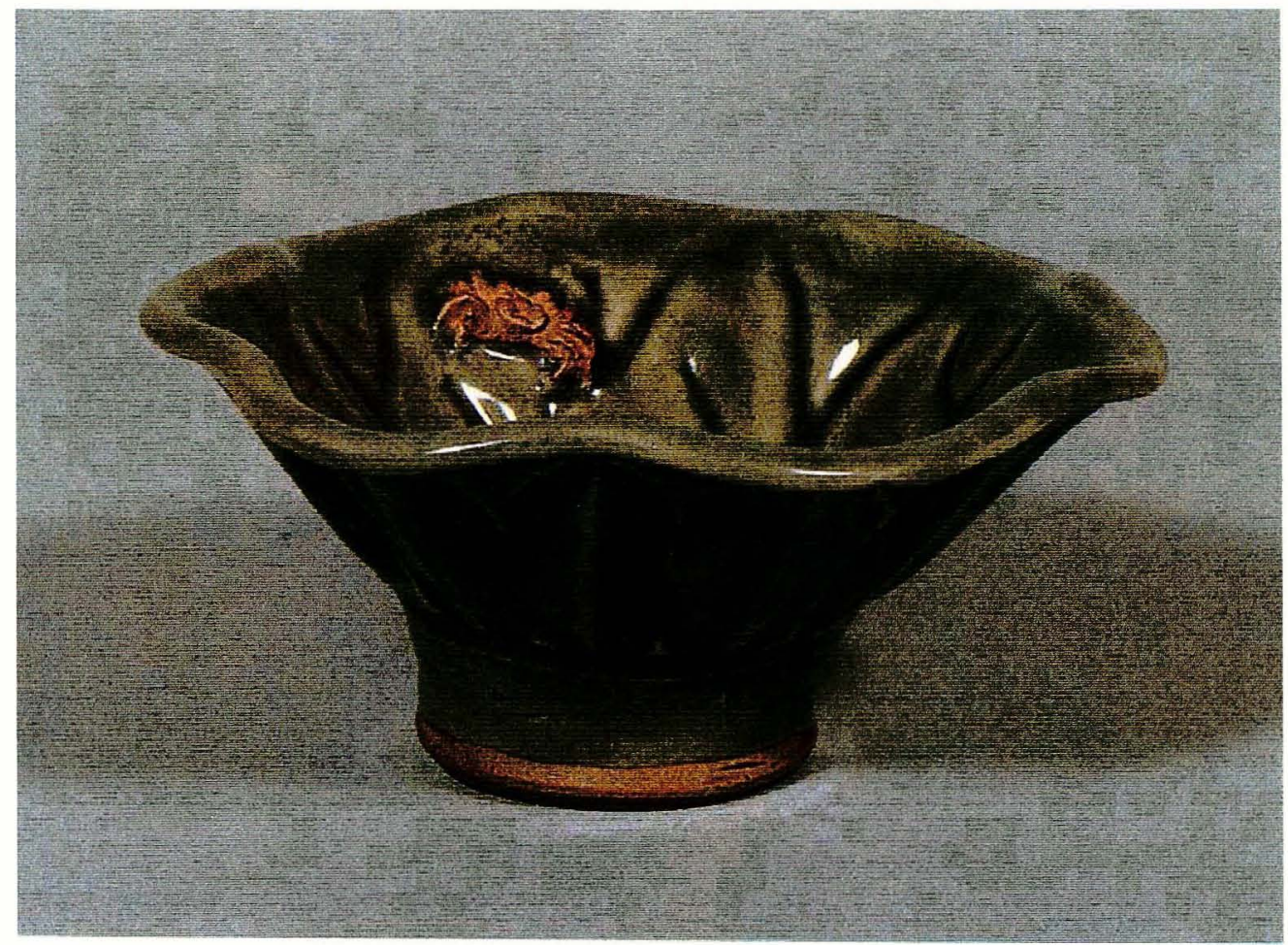

75 青磁 荷中君子籍洗 径13.

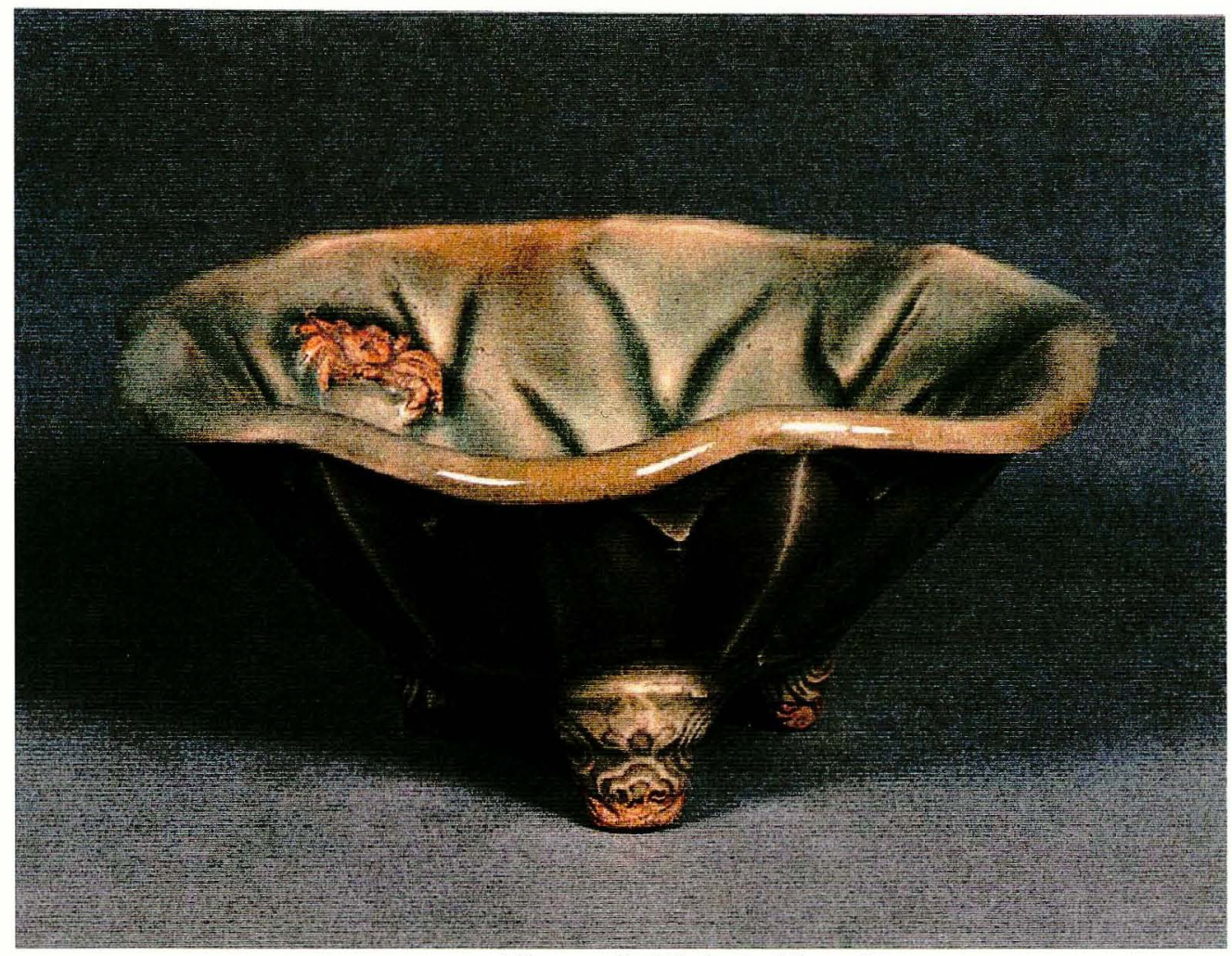

Figure 6- Mokubei bowl

(Original context, translated, Tadanari, Mitsuoka, (1990). Mokubei, Heibonsha, p76) 


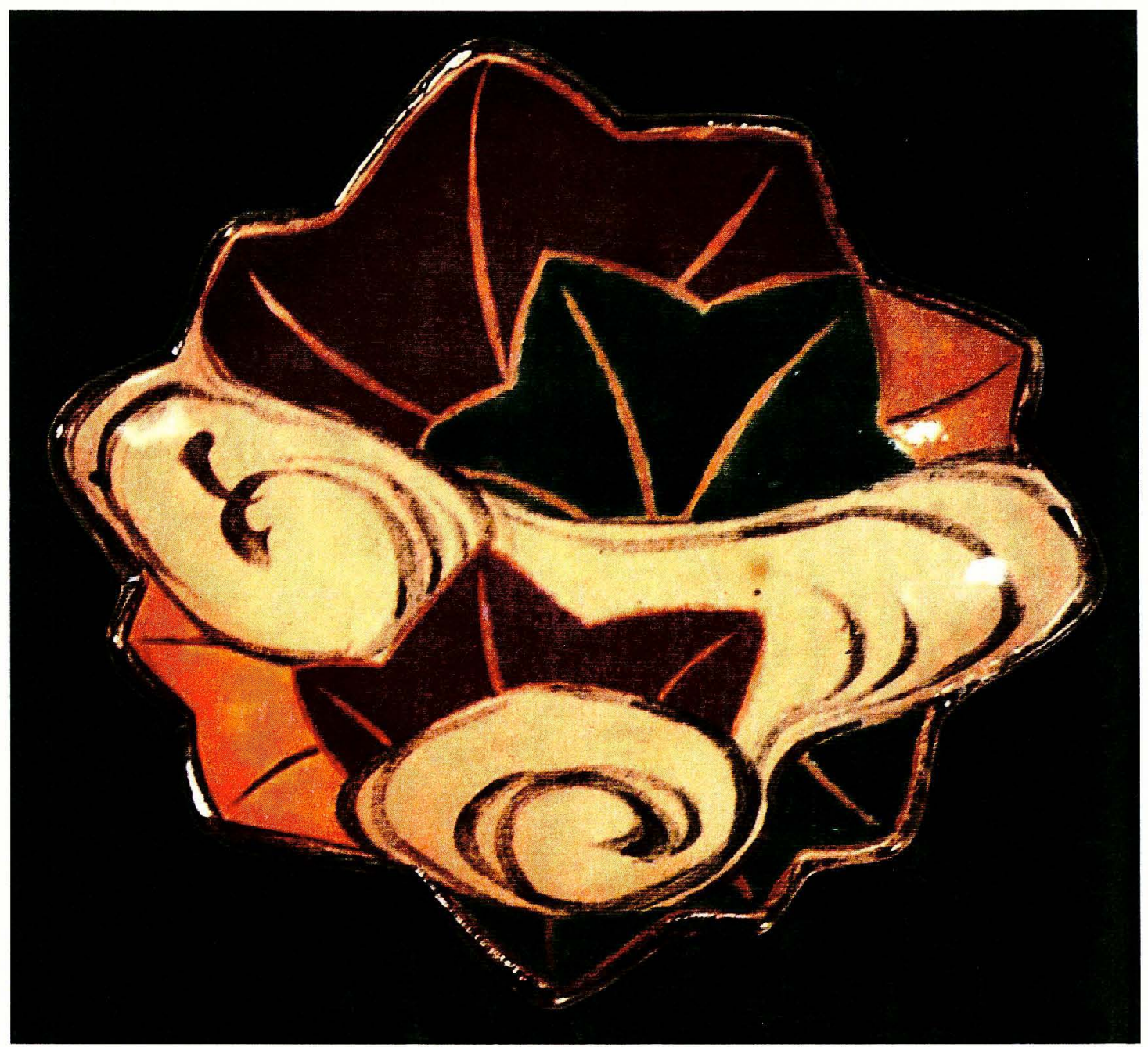

Figure 7- Kenzan dish

(Original context, Wilson, R., cover image)

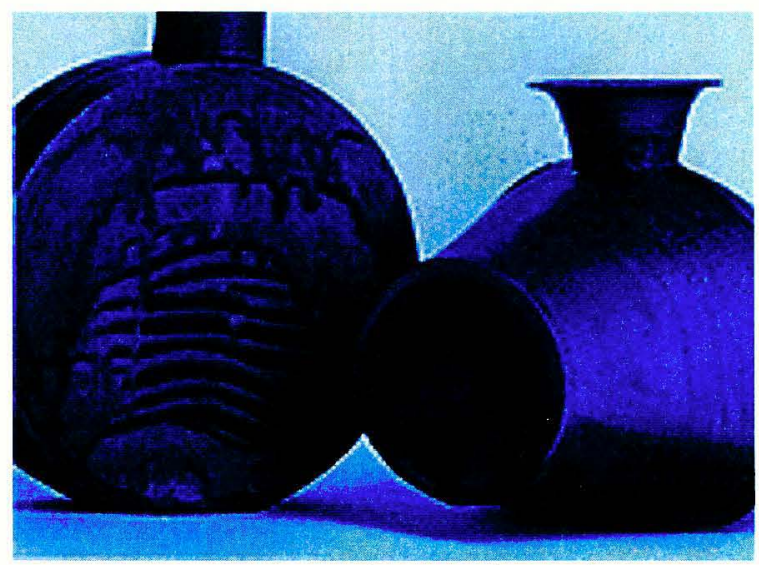

Figure 8- Nakazato rice bale

(original context, www.westword.com/issues/1999-12-23/art.html) 


\section{CONCLUSION}

The one issue I am continually faced with is, how I can make a pot more pleasant to use with such a dry matte surface. While I am partial to a quiet varied surface, it may not suit certain forms, plates and bowls for example. The surface does not work well with utensils scrapping against it. I will continue to research clays for the reduction cool wood kiln, trying to find a buff surface that still yields sufficient variation. Also, as an alternative, I will explore clays within the salt kiln that will produce a smooth surface, equally subtle. My process will continue to be honed and I will broaden my selection of stamps and molds, possible looking to textiles for additional inspiration. 


\section{BIBLIOGRAPHY}

Kuroda, Ryoji and Murayama, Takeshi, (2002). Classic Stoneware of Japan, Shino and Oribe, Kodansha International, New York

Pye, David, (1968). The nature and art of workmanship, University Press, Cambridge

Tadanari, Mitsuoka, (1990). Mokubei, Heibonsha

Wilson, Richard L. (1991). The Art of Ogata Kenzan, Persona and Production in Japanese Ceramics, Weatherhill, New York

www.westworkd.com/issues/1999-12-23/art.html 


\section{CURRICULUM VITAE \\ LINDSAY OESTERRITTER \\ 345 East 700 North \#B $\bullet$ Logan, UT 84321 \\ 502-533-9299 aoesterritter ayahoo.com}

\section{EDUCATION}

2006

Master of Fine Arts Candidate, Utah State University, Logan, UT

2006

Master of Arts, University of Louisville, Louisville, KY

2004

Summer Work-study, Utah State University, Logan, UT

2003

Kiln Building Workshop, University of Louisville, Louisville, KY

2000

Bachelor of Arts, Transylvania University, Lexington, KY

\section{SCHOLARSHIPS AND AWARDS}

2005

2004-2005

1999

$1996-2000$

$1996-2000$

\section{EXPERIENCE}

2006
Fellowship, Anderson Ranch Arts Center, Snowmass Village, CO

Hite Art Institute Scholarship, University of Louisville, Louisville, KY

Abbot Art Award, Transylvania University, Lexington, KY

Deans Recognition Scholarship, Transylvania University, Lexington, $\mathrm{KY}$

Fine Art Scholarship, Transylvania University, Lexington, KY
Teaching Assistant, Utah State University, Logan UT Assisted Alexa Sand with History of Western Art, Ancient to Medieval 
General Assistant, University of Louisville, Louisville, KY Maintained the community working space

2004-2005

President, Ceramic Arts Organization, Louisville, KY

Conducted biweekly meetings, organized annual pottery sale, informed club members on current news and opportunities

2003

Visiting Artist, Winners on Wheels, Louisville, KY Instructed a group of handicapped teenagers on how to 'have fun' with photography and ceramics, taught basic skills

\section{SOLO EXHIBITIONS}

2006

Variations Within Process, Thrown Together, 1806 Frankfort Avenue, Louisville, KY

\section{JURIED AND GROUP EXHIBITIONS}

International Cup, Allegra Print and Imaging, 40 West Lawrence, Helena, MT UT

One Time Only, Twain Tippetts Gallery, Utah State University, Logan, UT 
Graduate Student Art Exhibit, Twain Tippetts Gallery, Utah State University, Logan, UT

BA Exhibition, Morland Gallery, Transylvania University, Lexington, $\mathrm{KY}$

Three Dimensional Community, ArtsPlace Gallery, Lexington, $\mathrm{KY}$

Juried Student Exhibition, Morland Gallery, Transylvania University, Lexington, $\mathrm{KY}$ 